\title{
Malmographina, a new genus for Graphina malmei (Ascomycota: Ostropales: Graphidaceae)
}

\author{
Marcela Eugenia da Silva CÁCERES, Eimy RIVAS PLATA and \\ Robert LÜCKING
}

\begin{abstract}
The new genus Malmographina Cáceres, Rivas Plata \& Lücking is introduced for Opegrapha plicosa Meissn. (syn. Graphis malmei Redinger), with the new combination Malmographina plicosa (Meiss.) Cáceres, Rivas Plata \& Lücking. The taxon is characterized by prominent, striate, orangepigmented, non-carbonized lirellae, a more or less clear hymenium, and large, muriform, hyaline ascospores. Malmographina is most similar to Hemithecium in lirellae morphology and anatomy, but in a molecular phylogenetic analysis falls within a clade containing Phaeographis and other genera with usually inspersed hymenium and brown ascospores. Within that clade, it is thus far the only taxon that has persistently hyaline ascospores. It is otherwise similar to Pallidogramme but does not cluster within that genus. A preliminary phylogenetic analysis of the Phaeographis clade confirms monophyly of the genera Halegrapha, Pallidogramme, and Platygramme, and suggests that Phaeographis should be divided into several generic lineages and that Leiorreuma and Sarcographa perhaps be merged.
\end{abstract}

Key words: Amazonia, Brazil, Creographa, Ectographis, lichens, Peru, Phlegographa, Surinam

\section{Introduction}

Until most recently, genera within the Graphidaceae with lirellate ascomata were distinguished based on ascospore pigment and septation (hyaline versus grey-brown, transversely septate versus muriform), as well as ascoma organization [solitary versus (pseudo-)stromatic] into eight genera: Graphis, Phaeographis, Graphina, Phaeographina, Glyphis, Medusulina, Sarcographa and Sarcographina (Zahlbruckner 1923; Wirth \& Hale 1963, 1978). Staiger (2002) challenged this highly artificial concept and provided new genus circumscriptions based on a combination of morphological, anatomical, and

M. E. d. S. Cáceres: Departamento de Biociências, Universidade Federal de Sergipe, CEP: 49.500-000, Itabaiana, Sergipe, Brazil.

E. Rivas Plata and R. Lücking (corresponding author): Department of Biological Sciences, University of Illinois-Chicago, 845 West Taylor Street (MC 066), Chicago, Illinois 60607, USA. Email: rlucking@field museum.org

E. Rivas Plata: Department of Botany, The Field Museum, 1400 South Lake Shore Drive, Chicago, Illinois 60605-2496, USA. chemical features, distinguishing 22 genera. This concept was subsequently refined and tested with molecular data (Kalb et al. 2004; Archer 2006, 2009; Staiger et al. 2006; Lücking 2007; Lücking et al. 2007; Lücking \& Rivas Plata 2008; Mangold et al. 2008). These studies confirmed many of the taxa proposed by Staiger (2002) but challenged others, such as Graphis, which actually contains two unrelated lineages, and Hemithecium, which splits up into at least four separate lineages (Rivas Plata et al. 2011). One species, Hemithecium plicosum (Meissn.) Lücking \& Aptroot (syn. Graphina malmei Redinger), did not cluster with either Graphis or Hemithecium but fell within the clade containing Phaeographis and other grey-brownspored genera (Rivas Plata et al. 2011), even if its ascospores are persistently hyaline. This species (as Graphina malmei) was said to have uncertain affinities by Staiger (2002), but was subsequently included in Hemithecium by Lücking et al. (2008).

Here, we present a more detailed study of the Phaeographis clade to elucidate the exact position of Hemithecium plicosum and, based 

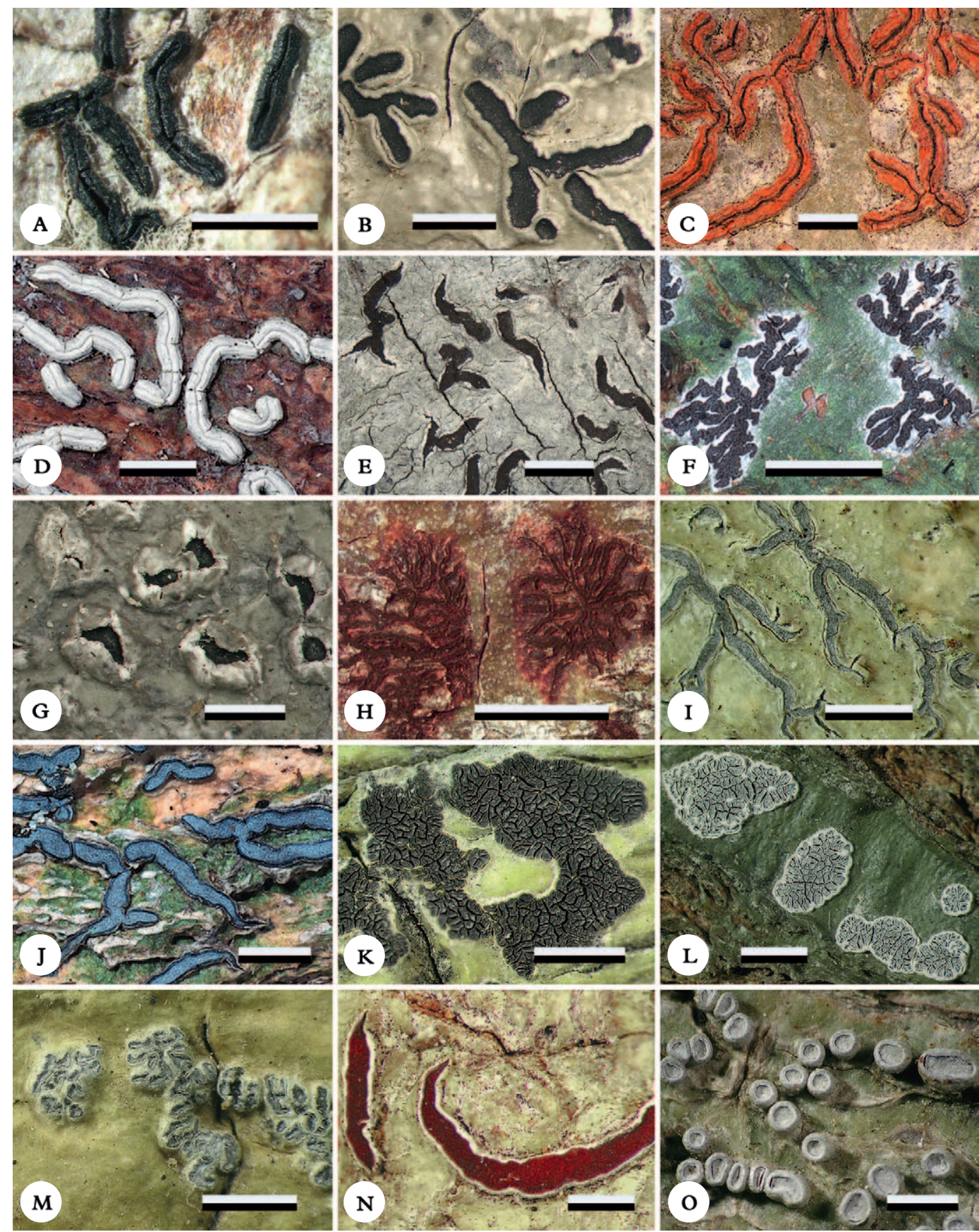
TABLE 1. GenBank accession numbers and voucher information (for newly generated sequences) for taxa used in this study.

\begin{tabular}{|c|c|c|c|c|c|}
\hline Genus & Species & mtSSU & nuLSU & Origin & Voucher \\
\hline Diorygma & poitaei & HQ639596 & HQ639627 & & \\
\hline Glyphis & cicatricosa & HQ639610 & HQ639630 & & \\
\hline Thalloloma & hypoleptum & HQ639609 & & & \\
\hline Halegrapha & chimera & JF505933 & & & \\
\hline Halegrapha & chimera & JF505934 & & & \\
\hline Hemithecium & plicosum & HQ639590 & & & \\
\hline Leiorreuma & hypomelaenum & DQ431971 & DQ431933 & & \\
\hline Pallidogramme & chlorocarpoides & JN127362 & & Philippines & Rivas Plata 2008b (F) \\
\hline Pallidogramme & chrysenteron & $\mathrm{JN} 127361$ & & Philippines & Rivas Plata 1157D (F) \\
\hline Phaeographis & brasiliensis & DQ431958 & & & \\
\hline Phaeographis & caesioradians & DQ431968 & & & \\
\hline Phaeographis & dendritica & HQ639592 & & & \\
\hline Phaeographis & intricans & DQ431960 & & & \\
\hline Phaeographis & lecanographa & DQ431983 & DQ431943 & & \\
\hline Phaeographis & leprieurii & JN127363 & JN127365 & Brazil & Cáceres s.n. (F) \\
\hline Phaeographis & lobata & DQ431984 & DQ431944 & & \\
\hline Phaeographis & scalpturata & JN127364 & & Peru & Rivas Plata 106A (F) \\
\hline Platygramme & australiensis & DQ431970 & & & \\
\hline Platygramme & caesiopruinosa & DQ431973 & & & \\
\hline Platygramme & caesiopruinosa & EU075593 & EU075639 & & \\
\hline Sarcographa & fenicis & DQ431967 & DQ431931 & & \\
\hline Sarcographa & glyphiza & DQ431972 & DQ431934 & & \\
\hline Sarcographa & labyrinthica & JF828969 & & & \\
\hline Sarcographa & ramificans & DQ431981 & DQ431942 & & \\
\hline Thecaria & montagnei & HQ639605 & & & \\
\hline Thecaria & quassiicola & JF828971 & & & \\
\hline Thecaria & quassiicola & HQ639617 & HQ639667 & & \\
\hline
\end{tabular}

on our findings, introduce the new genus Malmographina for this taxon.

\section{Material and Methods}

To elucidate the phylogenetic position of Hemithecium plicosum, we assembled a dataset consisting of the small subunit of the mitochondrial ribosomal DNA (mtSSU) and the large subunit of the nuclear ribosomal DNA (nuLSU) of selected species of the Phaeographis clade (Fig. 1), with Diorygma poitaei, Glyphis cicatricosa and Thalloloma hypoleptum as outgroup taxa (Table 1). Most sequences were downloaded from Genbank, but five sequences (see Table 1) were newly generated following the protocol outlined in Rivas Plata et al. (2011). The sequences were aligned using MAFFT (Katoh \& Toh 2005) and the alignment was subjected to maximum likelihood search using RAxML 7.2.6 (Stamatakis et al. 2005; Stamatakis 2006), with parametric bootstrapping using 1000 replicates under the GTRGAMMA model.

\section{Malmographina Cáceres, Rivas Plata \& Lücking gen. nov.}

MycoBank No: MB 563384

Genus novum familiae Graphidacearum. Thallus laevigatus, viridis. Lirellae proeminentes, striatae, aurantiacae. Excipulum crenatum, non-carbonizatum. Hymenium non inspersum. Ascosporae muriformes,

Fig. 1. Taxa of the Phaeographis clade analyzed for this study. A, Halegrapha chimaera (holotype); B, Leiorreuma exaltatum (Dominica, Imshaug 32934); C, Malmographina plicosa (Peru, Rivas Plata FM-09); D, Pallidogramme chrysenteron (Costa Rica, Lücking 15287t); E, Phaeographis dendritica (Argentina, Ferraro s.n.); F, Phaeographis intricans (Costa Rica, Lücking 15252e); G, Phaeographis kalbii (Costa Rica, Trest 1584i); H, Phaeographis leprieurii (Brazil, Cáceres s.n.); I, Phaeographis scalpturata (Brazil, Cáceres 523); J, Platygramme caesiopruinosa (Costa Rica, Lücking 15060k); K, Sarcographa fenicis (Brazil, Cáceres 12); L, Sarcographa labyrinthica (Brazil, Cáceres 21); M, Sarcographina glyphiza (Philippines, Merrill 9045); N, Thecaria montagnei (Trinidad and Tobago, Imshaug 32437);

O, Thecaria quassicola (Florida, Lücking 26626). 
hyalinae, leviter amyloideae. Acidi lichenum desunt sed lirellae antraquinonae continentes.

Typus: Malmographina plicosa (Meissn.) Cáceres, Rivas Plata \& Lücking, comb. nov. [Mycobank MB 563385].- Opegrapha plicosa Meissn., Bot. Zeitung 13: 422 (1855);-Hemithecium plicosum (Meissn.) Lücking \& Aptroot, Fieldiana, Botany 46: 65 (2008); lectotype (fide Lücking et al. 2008: 65): Surinam, Kegel 1419 (L!). = Graphina malmei Redinger, Ark. Bot. 26A(1): 49 (1933) [holotypus-Brazil, Malme 3508 (S!)].

(Fig. 1C)

Thallus smooth, olive-green (becoming yellowish in the herbarium), in section with dense, prosoplectenchymatous cortex and irregular photobiont layer intermingled with scattered clusters of calcium-oxalate crystals.

Lirellae erumpent to prominent, finely but distinctly striate, with orange to cinnabar-red pigment. Disc concealed. Excipulum distinctly crenate, orange-brown and becoming dark brown to carbonized in inner apical parts; old, compressed layers of hymenia between the excipular striae becoming dark brown to almost carbonized as well. Hymenium clear; epithecium with clusters of dark brown to blackish granules. Ascospores muriform, hyaline, non-amyloid.

Chemistry. No lichen substances detected in the thallus but lirellae with anthraquinones (tetrahydroxyanthrachinon-1,3,6,8 and other, unidentified pigments). For a more detailed description, see Staiger (2002: 452, as Graphina malmei).

Notes. Staiger (2002) discussed the systematic position of Graphina malmei as uncertain. Lücking et al. (2008) subsequently found an earlier name for this species, Opegrapha plicosa Meissn., and proposed the combination Hemithecium plicosum (syn. Graphina malmei), because of the prominent lirellae with well-developed labia and uncarbonized excipulum, and the hyaline ascospores. In a molecular phylogenetic analysis, however, Hemithecium was shown to be polyphyletic: one group including $H$. implicatum (Fée) Staiger clustered with Graphis Adans. s. str., another group including H. chlorocarpum (Fée) Trevis. clustered with
Allographa Chevall., a segregate of Graphis, while $H$. rufopallidum (Vain.) Staiger and $H$. plicosum formed separate lineages (Rivas Plata et al. 2011). Surprisingly, in spite of the hyaline ascospores, Hemithecium plicosum fell within a clade formed by Phaeographis and allied genera, all characterized by greybrown ascospores and a usually inspersed hymenium with inspersion of the Phaeographis type (Lücking 2009). Within that clade, Hemithecium plicosum is morphologically most similar to species of Pallidogramme, which also have Hemithecium-like, prominent, striate lirellae (and were included in Hemithecium by Staiger 2002) but differ in the grey-brown ascospores and usually inspersed hymenium (Staiger 2002; Lücking et al. 2008).

Our emended phylogenetic analysis of the Phaeographis clade (Fig. 2), although preliminary since only few species of this clade have been sequenced so far, confirms several of the genera distinguished by Staiger (2002) and in subsequent studies (Lücking et al. 2008, 2011), such as Halegrapha, Pallidogramme, Platygramme, and Thecaria s. str., as independent, monophyletic lineages. Phaeographis as circumscribed by Staiger (2002) is polyphyletic and forms several clades that are morphologically well distinguished: the $P$. lecanographa clade with Chapsa-like ascomata, the $P$. intricans clade (Creographa) with pseudostromatic ascomata and clear hymenium, the $P$. leprieurii clade (Phlegographa) including Glyphis-like species with nearly stromatic, heavily carbonized ascomata, the P. scalpturata clade (Ectographis) which contains the bulk of corticate species with pruinose disc, and Phaeographis s. str., a small clade characterized by ecorticate, whitish thalli and ascomata with chocolate-brown disc. Other oddball taxa within the Phaeographis clade also form separate lineages: Sarcographa fenicis with completely flattened, stromatic ascomata, Sarcographa glyphiza, whose generic position has been unclear, and Hemithecium plicosum, for which the new genus Malmographina is established here. The phylogeny also suggests that Leiorreuma and Sarcographa should be merged, but must await molecular analysis of the type species of 


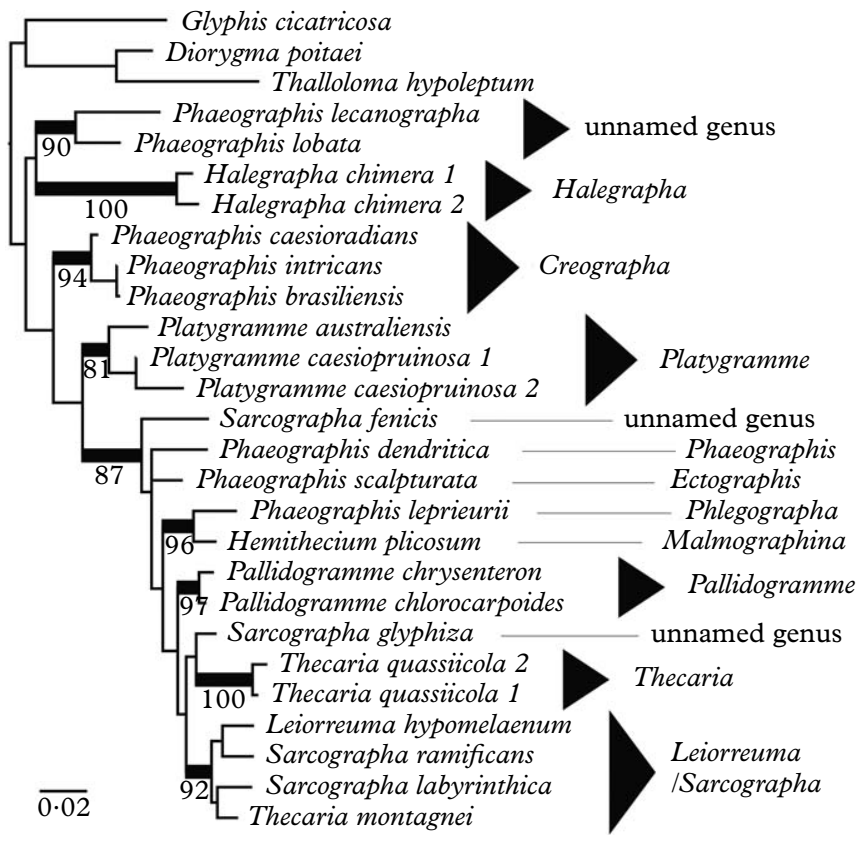

FIG. 2. Phylogeny of the Phaeographis clade derived by RAxML maximum likelihood analysis of a combined mtSSU-nuLSU dataset, using Diorygma poitaei, Glyphis cicatricosa, and Thalloloma hypoleptum as outgroup. Numbers below branches indicate bootstrap values.

Sarcographa, S. cinchonarum, before further conclusions can be drawn, as this species differs from the bulk of Sarcographa species centred around the common S. labyrinthica. It should also be noted that Thecaria montagnei clusters with the Leiorreuma-Sarcographa clade and not with $T$. quassiicola. This is not surprising as $T$. quassiicola is a morphologically unique species somewhat resembling Glyphis scyphulifera, whereas T. montagnei is very similar to Leiorreuma species except for the muriform ascospores and pigmented disc and hymenium.

Based on our results, it is appropriate to introduce a new genus, Malmographina, for Opegrapha plicosa (syn. Graphina malmei). Malmographina is distinguished from all other genera of Graphidaceae by the combination of Hemithecium-like (prominent, striate, uncarbonized) but pigmented lirellae, a clear hymenium, and hyaline, nonamyloid ascospores. Critical revision of the characters found in Malmographina suggests that the placement within the clade including Phaeographis and allied genera might not be that surprising after all. Lack of inspersion is found in a few lineages within this clade, including the Phaeographis intricans group and even a species of Pallidogramme, P. chapadana (Redinger) Staiger, Kalb \& Lücking (Staiger 2002). In species of Phaeographis and other genera with large, muriform ascospores, the ascospores often remain hyaline for a long time but eventually become at least pale grey-brown. In species of Pallidogramme with striate excipulum, such as P. chrysenteron (Mont.) Staiger, Kalb \& Lücking, mature ascospores become light gold-brown but the compressed, old hymenia between the excipular striae become very dark brown due to heavy pigmentation of collapsed, dead ascospores (Staiger 2002). We can therefore assume that Malmographina plicosa, which also shows heavy dark brown pigmentation of compressed old hymenia, has the potential to produce ascospore pigment but this only becomes expressed in postmature, collapsed and dead ascospores within excipular remnants. This is supported by the lack of iodine reaction of 
the ascospores which is more similar to that found in Phaeographis and allies than that typical of Graphis and Hemithecium.

Malmographina plicosa appears to be restricted to the Amazon basin. It is thus far known from Surinam (type of Opegrapha plicosa), Amazonian Peru (several collections from Madre de Dios province by Rivas Plata), Amazonian Brazil (several collections from Rondônia by Cáceres), and adjacent Mato Grosso (the type of Graphina malmei and collections made by Kalb). It prefers semi-exposed to exposed microsites mostly on bark of larger trees, where it can be found associated with other lichens having similar preferences, such as Glyphis spp., Phaeographis spp., and Trypetheliaceae.

The first author thanks CNPq - Conselho Nacional de Desenvolvimento Científico e Tecnológico (Edital Universal 2007 process no. 481884/2007-6 ) for supporting the study of crustose lichens in the Amazon and the Atlantic rain forest. This study was otherwise made possible by three grants provided by the United States National Science Foundation (NSF) to The Field Museum: "Phylogeny and Taxonomy of Ostropalean Fungi" (DEB 0516116; PI Lumbsch, Co-PI Lücking); "Neotropical Epiphytic Microlichens" (DEB 0715660; PI Lücking); and "ATM - Assembling a taxonomic monograph: The lichen family Graphidaceae" (DEB 1025861; PI Lumbsch, Co-PI Lücking).

\section{REFERENCES}

Archer, A. W. (2006) The lichen family Graphidaceae in Australia. Bibliotheca Lichenologica 94: 1-191.

Archer, A. W. (2009) Graphidaceae. Flora of Australia 57: 84-194.

Kalb, K., Staiger, B. \& Elix, J. A. (2004) A monograph of the lichen genus Diorygma - A first attempt. Symbolae Botanicae Upsalienses 34(1): 133-181.

Katoh, K. \& Toh, M. (2005) MAFFT version 5: improvement in accuracy of multiple sequence alignment. Nucleic Acids Research 33: 511-518.

Lücking, R. (2007) Kalbographa: Monografie einer unerkannten Flechtengattung. Bibliotheca Lichenologica 96: 185-192.

Lücking, R. (2009) The taxonomy of the genus Graphis sensu Staiger (Ascomycota: Ostropales: Graphidaceae). Lichenologist 41: 319-362.
Lücking, R. \& Rivas Plata, E. (2008) Clave y guía ilustrada para géneros de Graphidaceae. Glalia 1: $1-41$.

Lücking, R., Kalb, K., Staiger, B. \& Mcneill, J. (2007) Proposal to conserve the name Phaeographis, with a conserved type, against Creographa, Ectographis, Flegographa, Hymenodecton, Platygramma, Pyrochroa, and Pyrographa (Ascomycota: Ostropales: Graphidaceae), along with notes on the names Graphina and Phaeographina. Taxon 56: 1296-1299.

Lücking, R., Chaves, J. L., Sipman, H. J. M., Umaña, L. \& Aptroot, A. (2008) A first assessment of the Ticolichen Biodiversity Inventory in Costa Rica: the genus Graphis, with notes on the genus Hemithecium (Ascomycota: Ostropales: Graphidaceae). Fieldiana Botany, New Series 46: 1-126.

Lücking, R., Rivas Plata, E., Kalb, K., Common, R. S., Barcenas Peña, A. \& Duya, M. V. (2011) Halegrapha (Ascomycota: Graphidaceae), an enigmatic new genus of tropical lichenized fungi dedicated to Mason E. Hale Jr. Lichenologist 43: 1-13.

Mangold, A., Martín, M. P., Lücking, R. \& Lumbsch, H. T. (2008) Molecular phylogeny suggests synonymy of Thelotremataceae within Graphidaceae (Ascomycota: Ostropales). Taxon 57: 476-486.

Rivas Plata, E., Hernández, J. E., Lücking, R., Staiger, B., Kalb, K. \& Cáceres, M. E. S. (2011) Graphis is two genera - a remarkable case of parallel evolution in lichenized ascomycota. Taxon 60: 99-107.

Staiger, B. (2002) Die Flechtenfamilie Graphidaceae. Studien in Richtung einer natürlicheren Gliederung. Bibliotheca Lichenologica 85: 1-526.

Staiger, B., Kalb, K. \& Grube, M. (2006) Phylogeny and phenotypic variation in the lichen family Graphidaceae (Ostropomycetidae, Ascomycota). Mycological Research 110: 765-772.

Stamatakis, A. (2006) RAxML-VI-HPC: Maximumlikelihood-based phylogenetic analyses with thousands of taxa and mixed models. Bioinformatics 22: 2688-2690.

Stamatakis, A., Ludwig, T. \& Meier, H. (2005) RAxML-III: a fast program for maximum likelihood-based inference of large phylogenetic trees. Bioinformatics 21: 456-463.

Wirth, M. \& Hale, M. E., Jr. (1963) The lichen family Graphidaceae in Mexico. Contributions from the U.S. National Herbarium 36: 63-119.

Wirth, M. \& Hale, M. E. Jr. (1978) MordenSmithsonian expedition to Dominica: the lichens (Graphidaceae). Smithsonian Contributions to Botany 40: 1-64.

Zahlbruckner, A. (1923) Catalogus Lichenum Universalis 2. Leipzig: Borntraeger. 